九州大学学術情報リポジトリ

Kyushu University Institutional Repository

\title{
The Family Curculionidae of Japan : VI. Tribe Mechistocerini Part 2 (Insecta, Coleoptera)
}

Morimoto, Katsura

Entomological Laboratory, Faculty of Agriculture, Kyushu University

https://doi.org/10.5109/23855

出版情報：九州大学大学院農学研究院紀要. 31 (4)，pp. 345-364，1987-03-31. Kyushu University バージョン：

権利関係: 


\title{
The Family Curculionidae of Japan \\ VI. Tribe Mechistocerini Part 2 \\ (Insecta, Coleoptera) *
}

\author{
Katsura Morimoto \\ Entomological Laboratory, Faculty of Agriculture, \\ Kyushu University, Fukuoka 812, Japan \\ (Received December 8, 1986)
}

In the second part of the revision of the Mechistocerini, genera Rhadinomerus and Par. endymia are treated. New taxa are:Rhadinomerus unmon ryukyuensis subsp. nov., $R$. babai sp. nov., $R$. subovatus sp. nov., and $R$. ishigakianus sp. nov. Parendymia pilipes Kirsch is recorded from Japan for the first time.

\section{Rhadinomerus Faust}

Rhadinomerus Faust, 1892, Stett. ent. Zeit., LIII : 215 (type-species : Mechistocerus mastersi Pascoe, 1870, by original designation). -Faust, 1894, Ann. Mus. civ. Genova, XXXIV : 279. -Marshall, 1921,

Bull. ent. Res., XII : 170 (stridulatory apparatus). -Heller, 1937, Arb. morph. taxon. Ent. BerlinDahlem, 4 : 270. -Marshall, 1948, Novit. Zool., 42 : 439 (key to Burmese spp.). -Voss, 1958, Decheniana, Beih. 5 : 51 (Chinese spp.). -Morimoto, 1962, J. Fac. Agr., Kyushu Univ., $12: 61$. Morimoto, 1978, Esakia, (11) : 126. -Chao \& Chen, 1980, Econ. Ent. China, 20, Curc. (1) : 145. Mechistocerus (Rhadinomerus): Heller, 1904, Ent. Tidsk., 25 : 186 (African spp.). -Heller, 1921, Philipp.

J. Sci., 19: 581 (Philippine spp.).

Femora not or slightly clavate, not naked at base or the naked area limited to the anterior edge. Metasternum scarcely sulcate in the middle in female. First suture between first and second ventrites distinct throughout its length in both sexes. Male aedeagus with or without two short juxtaposed hairpin-shaped sclerites at gonopore.

\section{Key to species}

$1(2)$ Pronotum coarsely granulate-punctate, with a short median carina, black, opaque, with three small scaly patches at anterior margin ; elytra 1.6 times as long as broad, with dirty brick-red, brownish red or greyish red scales, intervals about as broad as punctures in the striae, each with a row of scales

2( 1) Pronotum punctate, not granulate.

3( 6) Male fore tibiae fringed internally with long setae ; elytra with a row of

* Contribution from the Entomological Labaoratory, Faculty of Agriculture, Kyushu University, Fukuoka (Ser. 3, No. 232). 
scales on each interval ; pronotum with the median carina vestigial or absent. unmon Nakane

4( 5 ) Elytra variegated with brownish and blackish scaly indefinite patches, punctures in striae deeper and as broad as intervals ‥unmonunmon Nakane

$5(4)$ Elytra densely covered with greyish to brownish grey scales except for the base and apex, punctures in striae smaller and a little narrower than intervals.

6( 3 ) Male fore tibiae not fringed internally with long setae.

7( 8 ) Elytra subcylindrical, 1.7-1.8 times as long as broad, with a conjoint broad scaly band at apical third; pronotum without median carina ; fourth ventrite with an irregular row or two rows of punctures in the middle.

- babai sp. nov.

8 ( 7 ) Elytra less than 1.7 times as long as broad; fourth ventrite with a regular row of punctures or scales in the middle; pronotum with a median carina before the middle.

9(10) Forehead between eyes with the median fovea vestigial or at most with an indistinct short sulcus; elytra weakly rounded laterally from fumeri to the middle, then roundly narrowing posteriad, broadest near the middle, striae with large punctures on basal half, much wider than intervals, the punctures suddenly diminished behind the middle, third interval weakly sinuate by subapical callus. subovatus sp. nov.

10(9) Forehead between eyes with a deep fovea or sulcus ; elytra parallel-sided on basal half, intervals scarcely narrower than punctures in striae on basal half, third interval not sinuate on declivity.

11(12) Elytra with three kinds of sparse scales, slender suberect scales arranged in a row on each interval, oval scales forming scattered indefinite small greyish patches, which are more or less transversely confluent on apical third, and minute prostrate scales on intervals ; punctures in striae suboval, not clearcut from the septa and intervals, but gradually hollowed.

ishigakianus sp. nov.

12(11) Elytra without a row of erect scales on each interval at leat on basal half, prostrate scales much denser and covering the majority of derm ; punctures in striae clear-cut and subquadrate.

maebarai Chûjô et Voss

\section{Rhadinomerus annulipes (Roelofs)}

(Figs. $1 \mathrm{~A} ; 2$ )

Cryptorhynchus annulipes Roelofs, 1879, Ann. Soc. ent. Belg., XXII, Compt. -rend.: LIV (Japon). Roelofs, 1880, Ann. Soc. ent. Belg., XXIV: 21.

Rhadinomerus annulipes: Morimoto, 1962, Sci. Bull. Fac. Agr., Kyushu Univ., 19: 352 (Shikoku, Kyushu). -Morimoto, 1984, Coleopt. Jap. in col., IV : 332, pl. 65, fig. 25 (Honshu, Shikoku, Kyushu, Ryukyus).

Male. Derm dull black; pronotum with scatterd clavate short setae, one in each puncture, and with three dirty red scaly patches along anterior margin, median one usually smaller ; elytra predominantly covered with dirty brick-red, brownish red or 


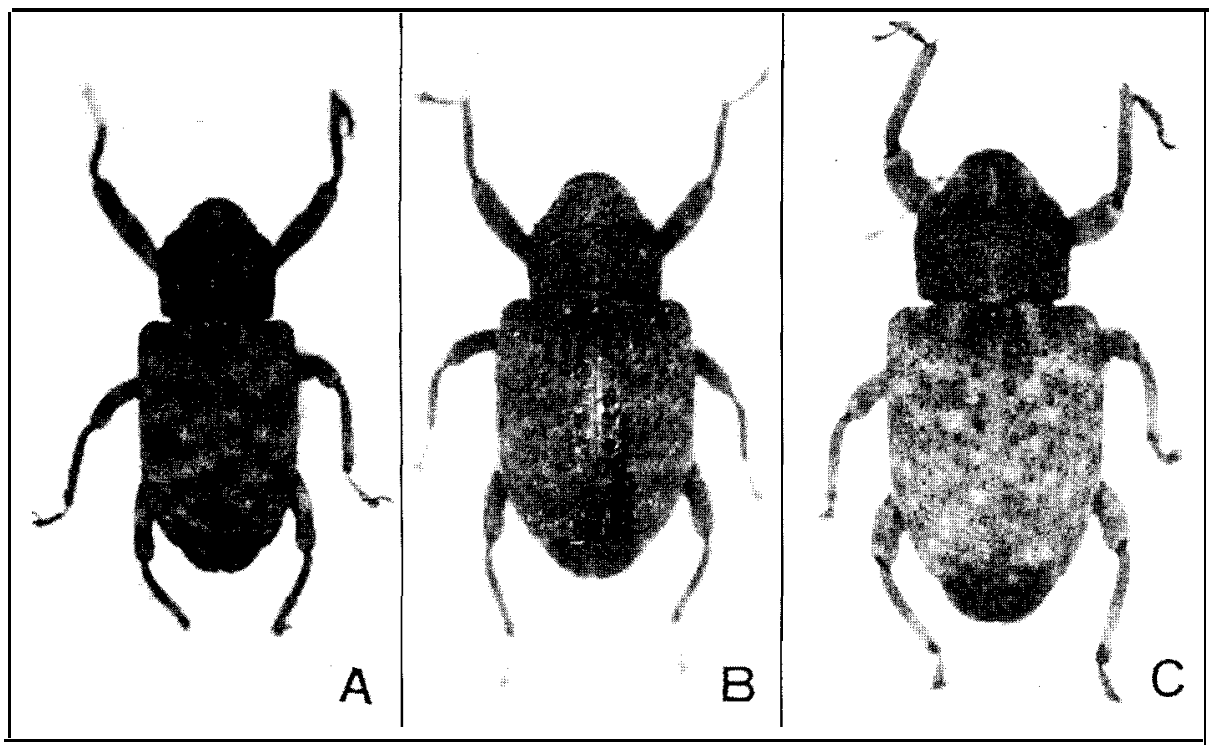

Fig. 1. Rhadinomerus spp. A :annulipes (Roelofs). B: unmon unmon $\mathrm{Nakane}$ (Mt. Tebako, Kochi). C:unmon ryukyuensis subsp. nov. (paratype, Iriomote I.).

greyish red scales, basal margin except for third interval and humeri scarcely scaled and visibly black, apical area behind subapical calli with brownish black scales and/ or with scarce reddish scales and visibly black.

Head with vertex bare, coarsely with shallow punctures, forehead minutely punctate smooth median area including a short sulcus, each puncture with a short scale. Rostrum as long as pronotum, constricted at the base, coarsely punctate and tricarinate on basal half, the median carina distinct, sparsely with very fine punctures on apical half. Antennae inserted in the middle of rostrum, scape clavate, with a few scales, three basal segments of funicle not pubescent, first segment as long as second, robust, third segment subequal to each of subsequent segment in length, 5/8 times as long as second, fourth segment sparsely pubescent, 1.5 times as long as broad, fifth to seventh segments pubescent, a little broader than fourth, club compact, 2.6 times as long as broad, first segment oblique at apex, about as long as the rest.

Pronotum slightly broader than long, broadest just before the middle, straightly and weakly narrowed posteriorly, roundly narrowed anteriorly to shallow subapical constriction, dorsum longitudinally convex basally and depressed in front, granulatepunctate, with a shiny median short carina. Scutellum circular, convex, bare, dull.

Elytra 1.6 times as long as broad, parallel-sided from humeri to the middle, subapical calli weak, striae with subquadrate close punctures that diminish behind the middle, intervals as broad as or slightly narrower than striae on basal half, third interval a little raised at base, each interval with a row of scattered suberect scales.

Legs dull black, femora predominantly with brownish red scales, with dark median and apical indefinite rings ; tibiae straight externally, blackish on basal half in 


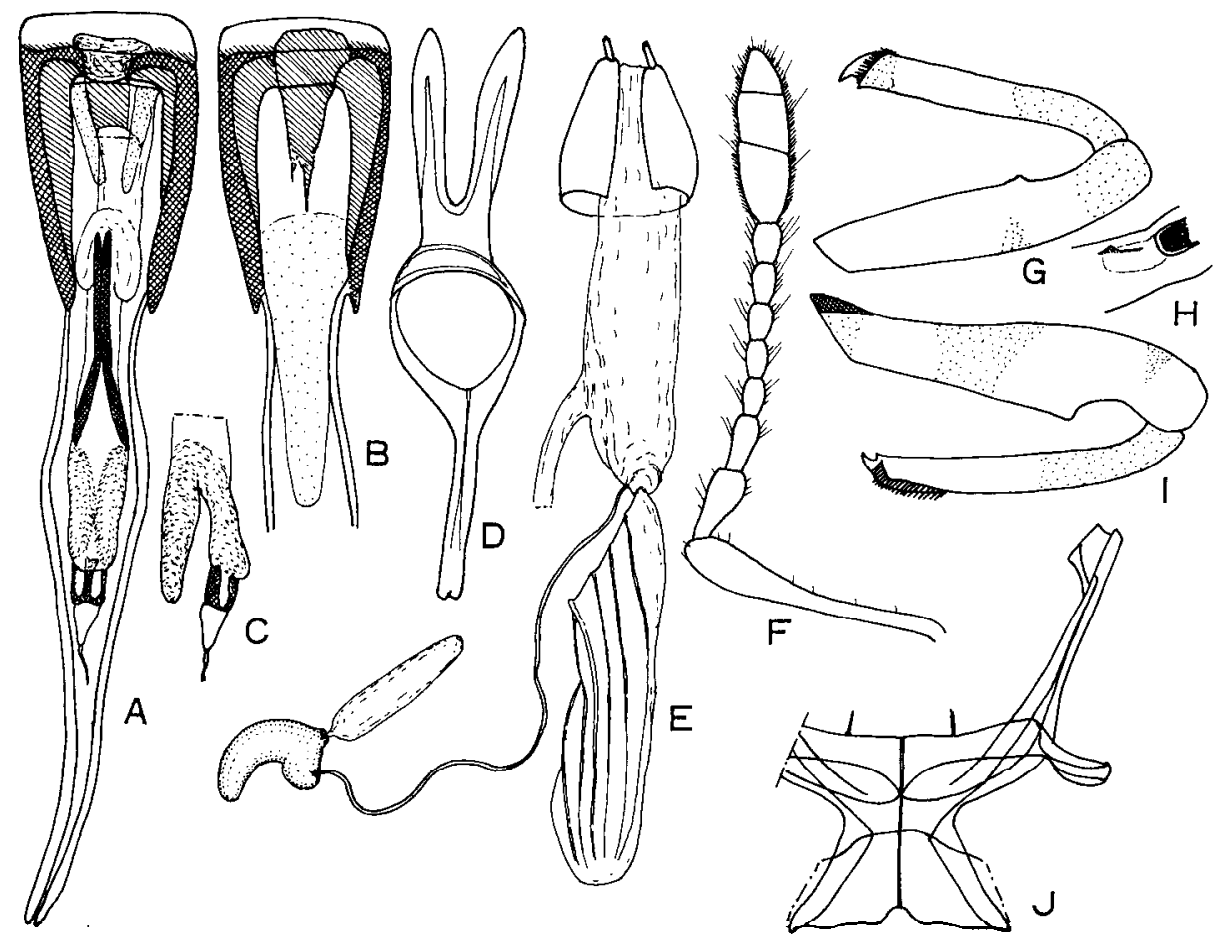

Fig. 2. Rhadinomerus annulipes (Roelofs). A: Penis, dorsal. B: Ditto, ventral. C: Gonopore, lateral. D: Tegmen and parameres. E: Female genitalia. F: Antenna. G : Fore leg. H : Femoral tooth of fore leg, anterodorsal. I : Hind leg. $\mathrm{J}$ : Metendosternite.

general.

Underside coriarious, with slight lustre ; metasternum with reticulate deep punctures, more or less sulcate longitudinally in the middle, anterior and posterior ends of the sulcus deeper ; first ventrite as densely punctate as on metasternum but the punctures smaller especially at sides, second to fourth ventrite with small dense punctures at sides and scattered fine punctures in the middle, each puncture with a scale, third and fourth ventrite each with a row of scales in the middle, fifth ventrite with small punctures, their interstices as broad as the diameters.

Aedeagus with penis dilated apically, broadly truncate at apex, apical orifice one third the width of penis, without a median sensillum, gonopore with two short juxtaposed hairpin-shaped sclerites.

Female. Antennae inserted in the middle of rostrum ; rostrum tricarinate on basal third ; metasternum with a median longitudinal depression ; first ventrite convex ventrally.

Length : 3.8-6.9 mm.

Specimens examined : 117 specimens from Izu Isls. (Niijima, Kozu, Miyake, 
Mikura, Hachijo, Aogashima), Wakayama, Kochi, Fukuoka, Chikuzen-Okinoshima I., Tsushima, Kagoshima, Yakushima I., Nakanaoshima I., Amami-Oshima I., and Okinawa I.).

Distribution : Japan (Honshu, Shikoku, Kyushu, Izu Isls., Tsushima, Ryukyus).

This species is easily recognized by the reddish scales on the elytra and the granulate-punctate pronotum. This is close to granulicollis Faust from Burma, but separable from it by the following points.

granulicollis : Scutellum punctate; pronotum broadest at the middle ; elytra with striae strongly punctate, much wider than intervals.

annulipes: Scutellum smooth, convex ; pronotum broadest before the middle ; elytra weakly punctate, striae as broad as or slightly broader than intervals on basal half.

\section{Rhadinomerus unmon unmon Nakane}

(Figs. 1B;3A-E)

R hadinomerus unmon Nakane, 1963, Fragm. Coleopt., (9/10): 38 (Mie : Hirakura). -Nakane, 1963, Icon. Ins. Jap. col. nat. ed., II :371, pl. 186, fig. 8. -Morimoto, 1984, Coleopt. Jap. in col., IV : 332, pl. 65, fig. 23. (Honshu, Shikoku, Kyushu).

Male. Derm dull black ; each puncture of pronotum with a scale, brownish black scales narrower and suberect, greyish brown scales denser before subapical constriction, greyish scales forming three indefinite stripes, median one often interrupted in the middle or obliterated behind the middle, lateral ones dorso-lateral, divergent posteriorly and obliterated behind the middle; elytra variegated with brownish and blackish scaly indefinite patches, third interval with a short brownish stripe at the base, each interval with a row of scattered suberect scales.

Head with vertex bare, coarsely with a shallow punctures, forehead with dense punctures, which a little smaller than those on vertex and entirely covered with brownish grey scales in fresh specimens, with a deep oval fovea. Rostrum slightly constricted at the base, tricarinate on basal half, with two rows of punctures between carinae, densely scaled towards the base, reddish brown with scattered fine punctures before the middle. Antennae inserted just before the middle of rostrum, scape clavate at apex, with a few pubescence, funicle pubescent from first segment, first segment robust, slightly shorter than second $(7: 8)$, second segment slender, 2.5 times as long as broad, remaining segments subequal in length, sixth segment $6 / 5$ times as long as broad, seventh segment a little broader than sixth, club three times as long as broad, first and second segments equal in length.

Pronotum 1.12-1.22 times as broad as long, broader in larger specimens, rounded at sides, broadest at the middle, subapical constriction distinct at sides, dorsum longitudinally convex basally and depressed in front, more convex in larger specimens, reticulately punctate, median carina absent. Scutellum subcircular, with a few punctures, bare.

Elytara 7/10 times as broad as long, $3 / 2$ times as broad between humeri as the base of pronotum, parallel-sided from humeri to the middle, subapical calli weak, striae with subquadrate deep punctures that diminish behind the middle, their septa as 


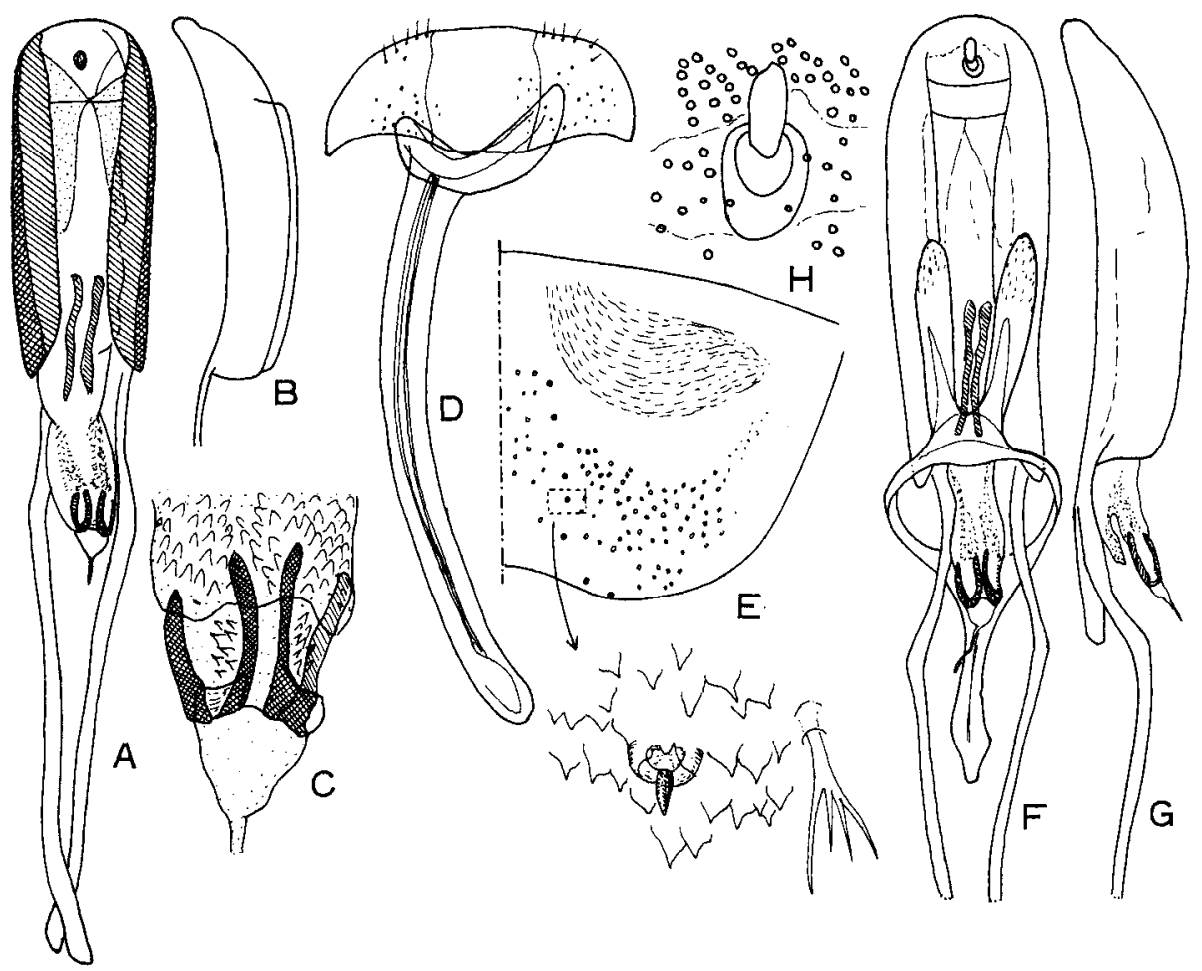

Fig. 3. A-E: Rhadinomerus unmon unmon Nakane, of (Mt. Tebako, Kochi). A: Penis, dorsal. B : Ditto. lateral. C : Gonopore, enlarged. D : Genital segment. E : Propygidium (7th tergite) and a scraper, enlarged. F-H : Rkadinomerus unmon ryukyuensis subsp. nov. (Amami-Oshima). F : Penis, dorsal. G : Ditto, lateral. H : Sensillum near apex of penis, enlarged.

long as the width of intervals, intervals as broad as punctures in striae at the base, each interval with a row of scattered scales, the scales blackish on blackish patches and brownish on brownish patches.

Legs dull black or with slight reddish tinge ; femora greyish with brownish median and apical indefinite rings, median ring often broad ; tibiae straight, brownish on basal third to fourth, then greyish to apex ; fore tibiae fringed internally with sinuate silvery long setae excepting the basal third; fore tarsi with long silvery setae; these long setae indistinct in small specimens.

Underside coriarious at least at sides ; metasternum with dense punctures, their interstices as broad as or a little narrower than the diameters, with a deep median sulcus ; first, second and fifth ventrites with punctures smaller than those on metasternum, their interstices as broad as the diameters on the median area, second ventrite impunctate along hind margin, third and fourth ventrites each with a row of scaled punctures in the middle ; seventh tergite with a pair of small stout spines.

Aedeagus with penis parallel-sided and broadly rounded at apex, with a character- 
istic sensillum near apex, internal sac with two short juxtaposed hairpin-shaped sclerites at gonopore.

Female. Antennae inserted in the middle of rostrum ; rostrum with median carina obliterated, lateral carinae on basal fourth weak, scaled at the base ; fore tibiae and tarsi not fringed with long setae.

Length : 3.6-6.5 mm.

Specimens examined : 40 specimens from Hokkaido (Sapporo, Jozankei), Aomori (Shimokita), Niigata (Kurokawa), Shizuoka (Misakubo), Kochi (Mt. Tebako), Fukuoka (Mt. Kumado), Oita (Mt. Sobo), Yakushima I., and Korea (Jejudo I.).

Distribution : Japan (Hokkaido, Honshu, Shikoku, Kyushu, Yakushima I.), Korea.

This species is easily recognized by their relatively broader elytra to the base of pronotum, lack of median carina on pronotum, and the fringed fore tibiae and tarsi in the male.

The specimens from the Ryukyus differs from the nominate population and are named here as an indipendent subspecies as follows.

\section{Rhadinomerus unmon ryukyuensis subsp. nov. \\ (Figs. $1 \mathrm{C} ; 3 \mathrm{~F}-\mathrm{H})$}

Differing from the nominate subspecies in the following points.

Elytra densely covered with brownish, brownish grey and greyish scales, basal margins of elyra except for third intervals and humeri blackish, apical area between

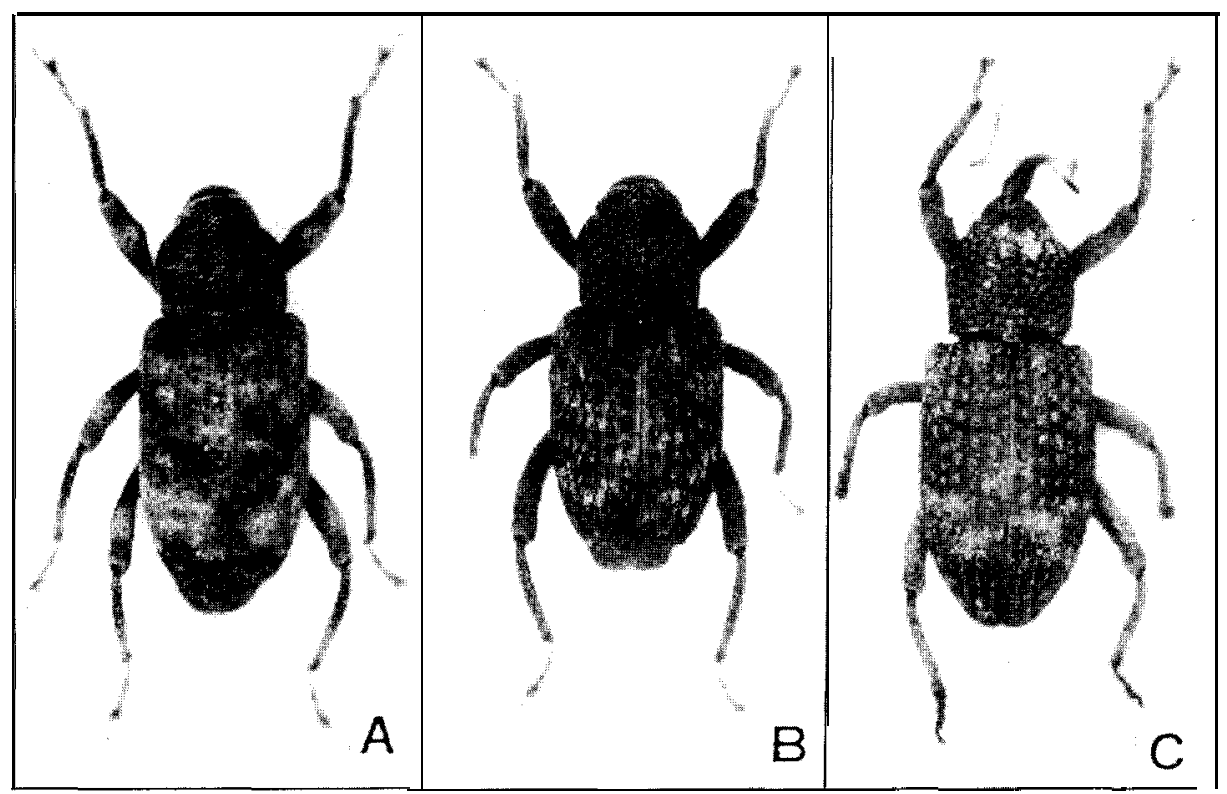

Fig. 4. Rhadinomenus spp. A : babai sp. nov. (paratype). B:subovatus sp. nov (paratype). C : ishigakianus $\mathrm{sp}$. nov. (holotype). 
and behind subapical calli predominantly blackish, punctures in striae smaller and a little narrower than intervals ; rostrum with median carina not obliterated but short at the base.

Length : 3.5-6.8 mm.

Holotype male (Type No. 2594, Kyushu Univ.), Mt. Yuidake, Amami-Oshima, 3. ix. 1983, K. Hirano leg.

Paratypes : Tokara-Nakanoshima I., 2 우, 25. iv. 1975, H. Irie leg. Mt. Yuidake, Amami-Oshima I., $2 \sigma^{\circ}+$, 21. vii, 1980, N. Yamamoto leg. ; same data as holotype, 1 우. Nishinakama, Amami-Oshima I., 1 우, 13. vii. 1962, H. Kawai leg. ; 1 우, 26. vii. 1969, H. Makihara. leg. ; 2648, 1-7. vi. 1970, H. Makihara leg. ;1 $\delta^{7}, 24$. v. 1978, H. Makihara leg. Hatsuno, Amami-Oshima I., 1 우, 25. vii. 1962, Y. Miyake leg. ; 261 오, 28. vii. 1962, H. Kawai leg. ; 3 우, 18. vi. 1963, J. Nagao leg. Mt. Yuwandake, AmamiOshima I., 1우, 16. vii. 1963, C. M. Yoshimoto leg. ;1우, 31. vii. 1963, L. Gressitt leg. ; 1 가 1 우, 1. ix. 1983, K. Hirano leg. Torigamine, Sumiyo-son, Amami-Oshima I., 161 우, 8. iv. 1977, T. Ogasawara leg. Chuo-rindo, Amami-Oshima I., $1 \sigma^{71} 1$ 우, 30. vi. 1980, R. Noda leg. Mt. Rankan, Amami-Oshima I., 1우, 12. viii. 1961, K. Yamada leg. Santaro-toge, Amami-Oshima, 1 ㅇ, 15. vii. 1935, Esaki \& Yasumatsu leg, ; Ikari, Amami-Oshima I., 16, 6. vii. 1974, K. Yamada leg. Mikyo, Tokunoshima I., 1ㅇ, 27. vii. 1963, L. Gressitt leg. Yona, Okinawa I., $1 \sigma^{7}$. 25. iv. 1965. K. Iha leg. ; 1 ${ }^{7}$, 26. iv. 1965, Y. Hirashima leg. ;

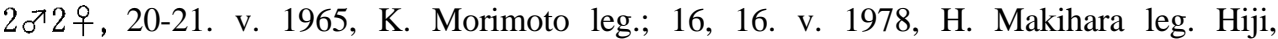
Okinawa I., $20^{7} 5$ 우, $3 \&$ 8. vii. 1974, T. Mikage leg. Yonahadake, Okinawa I., 1 우, 6. vii. 1974, T. Mikage leg. Kijoka, Okinawa I., 1\%, 22. v. 1961, 0. Nakachi leg. Hirara, Miyako I., 1우, 17. viii. 1969, H. Makihara leg. Mt. Omotodake, Ishigaki I., 1ヶ7, 14. x. 1963, S. Ueno leg. 1우, 9. iv. 1974, C. Yamada leg. ;1 $\sigma^{7}$. 11. vi. 1974, T. Mikage leg. ;2 그웅, 18. iv. 1975, H. Irie leg. Mt. Banna, Ishigaki I., 1 우, 7. x. 1963, K. Morimoto leg. ; 1우. 24. viii. 1969, H. Makihara leg. Ishigaki I., 1우, 2. viii. 1962, Y. Hama leg.

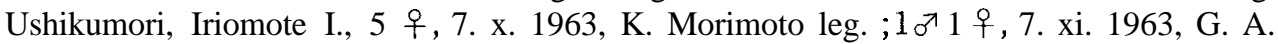
Samuelson. Shirahama, Iriomote I., 2 우, 4. x. 1963, S. Ueno leg. ; 1 우, 31. viii. 1968, H. Makihara leg. Kampira Fall, Iriomote I., 1 우, 14. vi. 1975, H. Irie leg.

Distribution : Japan (Ryukyus).

\section{Rhadinomerus babai sp.nov.}

(Figs. 4A; 5)

Male. Derm black, shiny ; pronotum with a pair of greyish brown scaly lateral stripes, which often abbreviated behind the middle and denser at anterior margin, often with a short median scaly stripe on basal half; elytra with two brownish grey to greyish scaly bands, anterior band on basal third irregular and mixed with blackish patches, posterior band on apical third more definite and broader, base of third interval with brownish grey scaly stripe, the rest with blackish scales.

Head with vertex reticulately punctate, forehead with small punctures, their interstices coriarious, with several scales, median fovea weak, often indefinite. Rostrum as long as pronotum, constricted at the base, sharply tricarinate at basal half, median carina slightly dilated apically from the basal two-thirds, with two rows of punctures between carinae, apical half reddish brown, with scattered fine punctures. 

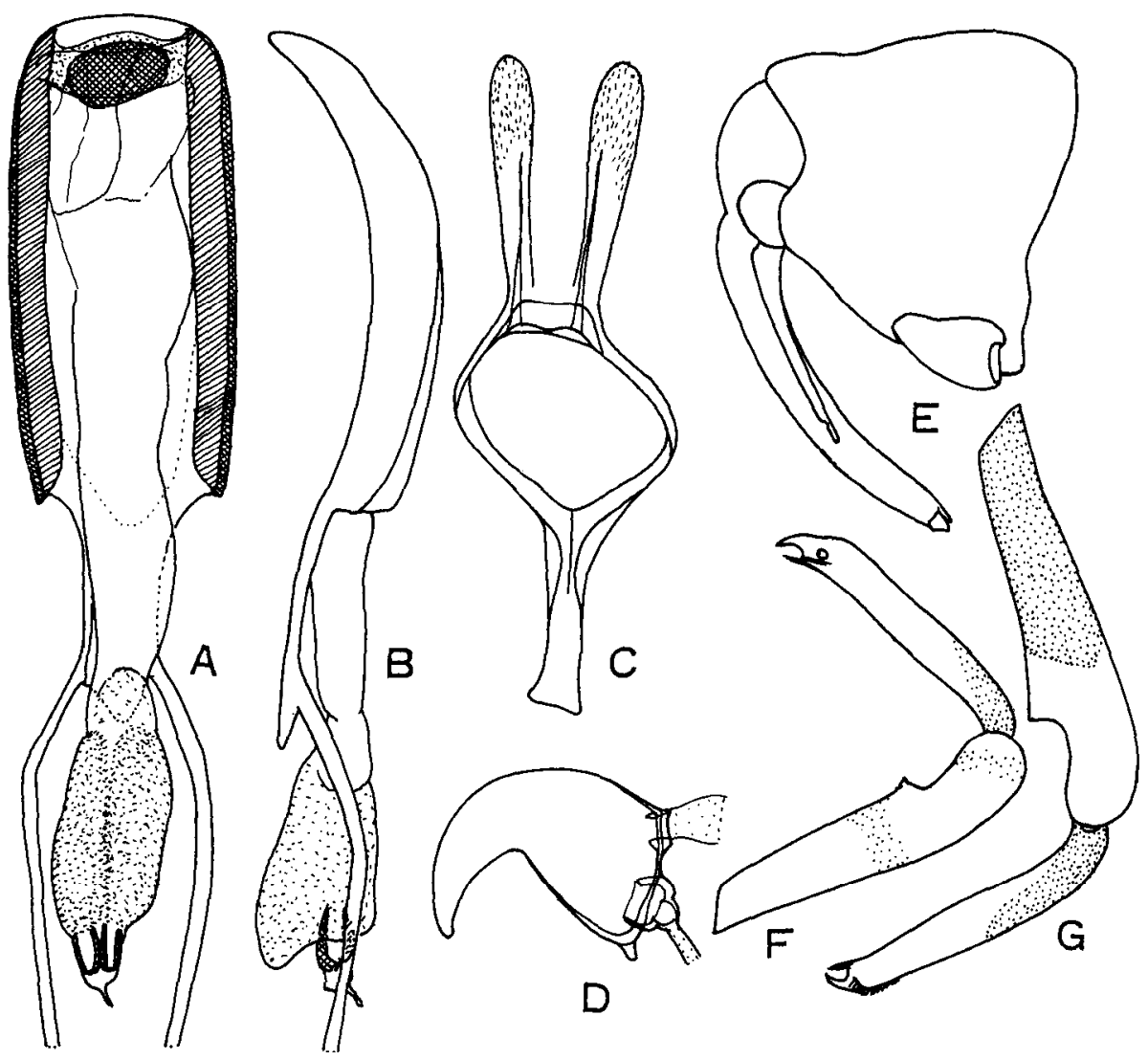

Fig. 5. Rhadinomerus babai sp. nov., ơ (except D 우). A : Penis. dorsal. B : Ditto, lateral. C: Tegmen and parameres. D: Spermatheca. E: Head and prothorax, lateral. F: Hore leg. G : Hind leg.

Antennae inserted before the middle of rostrum, funicle sparsely pubescent on basal two segments, the rest densely pubescent, first segment robust, as long as second, third to seventh segments subequal in length, $2 / 3$ the length of second, fourth segment excepting the stalk as long as broad, sixth and seventh segments transverse, club as long as basal two segments of funicle combined, 2.5 times as long as broad, first segment oblique at apex, as long as second.

Pronotum slightly broader than long, broadest at the middle, weakly and straightly narrowing posteriorly, dorsum weakly and longitudinally convex basally and slightly depressed in front, with reticulate punctures, their interstices shiny, much shorter than the diameters, median carina fine, abbreviated on basal third, often entirely absent, shiny. Scutellum punctate, with fine setae.

Elytra subcylindrical, 1.7-1.8 times as long as broad, parallel-sided on basal 2/3, subapical calli weak; punctures in striae much narrower than intervals on basal half 
and diminished behind, their septa shorter than the width of intervals, each interval with a row of scattered suberect short scales on the greyish bands.

Legs black with reddish brown tarsi; femora densely punctate, each puncture with a scale, fore femora with brownish grey scales, middle and hind femora with dense brownish grey scales on apical third ; tibiae similarly scaled as on femora, exterior basal margins with darker scales.

Underside coriarious at sides, shiny in the middle ; metasternum reticulately punctate at sides, separately punctate in the median smooth area, the latter area weakly depressed, not sulcate, transversely depressed along receptacle and a small depression at the base in the middle ; punctures on venter smaller than those on the sides of metathorax, third and fourth ventrites with one or two irregular rows of punctures, fifth ventrite with reticulate punctures.

Aedeagus with penis parallel-sided, broadly rounded at apex, ventral wall not pigmented except the periphery, apical orifice normal, without special sensillum near apex, internal sac with two short juxtaposed hairpin-shaped sclerites at gonopore, without sclerites in the middle.

Female. Rostrum with a short weak carina at the base, punctate on each side of the carina and along dorsal margin of scrobe; antennae inserted in the middle of rostrum ; metasternum flat in the middle.

Length : 4.3-7.8 $\mathrm{mm}$.

Holotype male (Type No. 2595, Kyushu Univ.), Mt. Tebako, Kochi Pref., 21. vii. 1955, K. Kojima leg.

Paratypes : Kurokawa, Niigata Pref., $2 \sigma^{-1} 8$ 우. 30. viii. 1963, bred by K. Baba from Phellodendron amurense (Rutaceae ; Kihada in Japanese). Hiratsuto, Iwate Pref., $1 \sigma^{7}$, 26. vii. 1980, I. Matoba leg. Kiso-Fukushima, Nagano Pref., $1 \sigma^{7}, 31$. vii 1953, S. Ueno leg. Yoshibu, Kuju, Oita Pref., $1 \sigma^{\top 1} 1$ 우, 1-2. vi. 1985, S. Urushiyama. Mt. Kurodake, Kuju, Oita Pref., 1우, 20. ix. 1985, S. Ogata leg.

Distribution : Japan (Honshu, Shikoku, Kyushu).

This new species is similar to several species of Mechistocerus with subcylindrical body, but the metasternum is not sulcate in the middle, the scales on the third and fourth ventriates are one or two rowed in the middle, the first suture between first and second ventrites are of the same depth throughout, and the male aedeagus has characteristic sclerites of Rhadinomerus at the gonopore.

The propygidium of the male abdomen is adorned with eight stout spines in a row on each side of the middle (scrapers) and their diameters are three times as large as those of adjacent punctures.

The name is dedicated to Dr. Kintaro Baba, who confirmed the host tree of this new species.

\section{Rhadinomerus subovatus sp. nov.}

(Figs. 4B; 6)

Male. Derm dull black, elytra and legs often with reddish tinge ; pronotum with scattered small dirty greyish scales, without patches; elytra with indefinite small yellowish grey to greyish scaly patches, which tend to form irregular broken trans verse bands, and a short stripe at the base of third interval. 


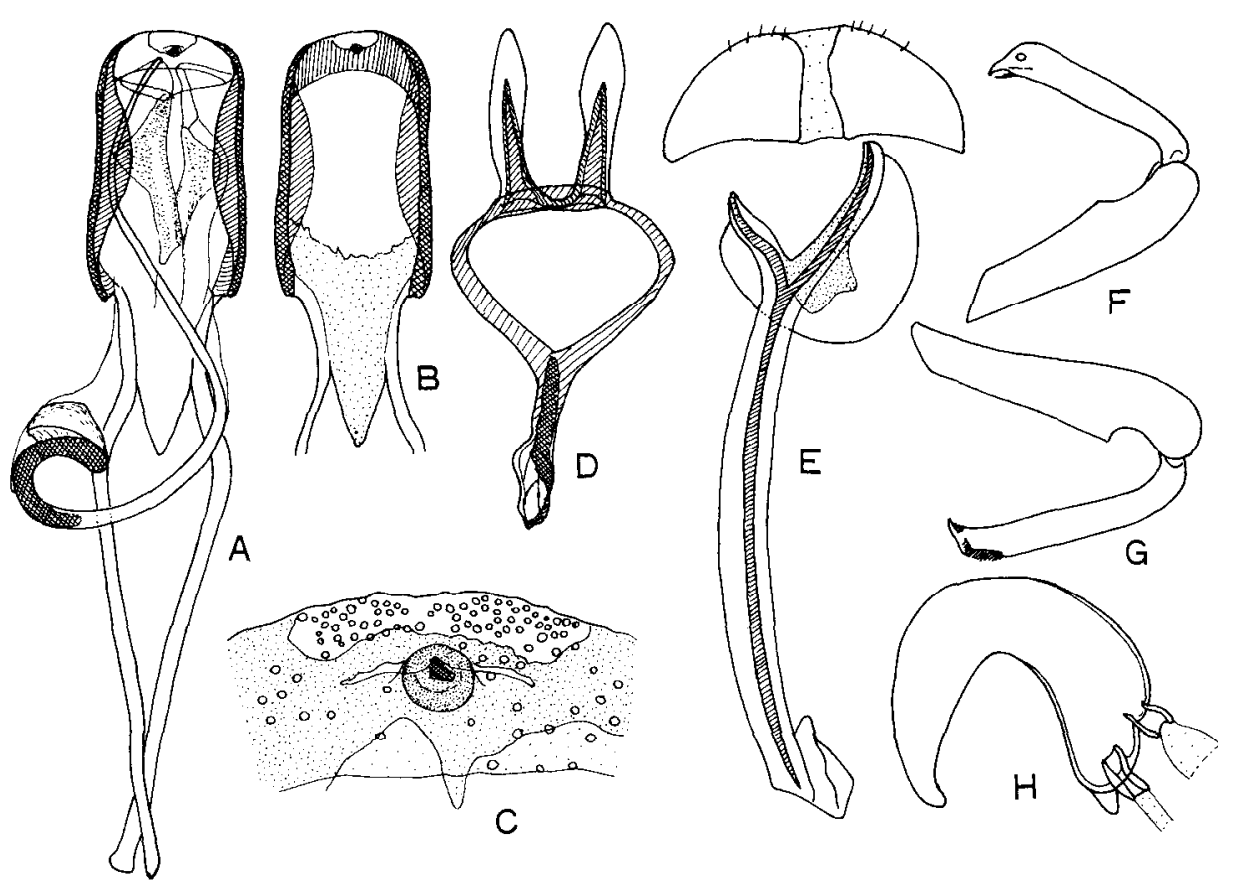

Fig. 6. Rhadinomemus subovatus sp. nov., $\vec{o}$ (except $\mathrm{H}$ 우). A: Penis, dorsal. B: Ditto, ventral. C: Apex of penis, enlarged, showing sensillum. D: Tegmen and parameres. E: Genital segment. F : Fore leg. G : Hind leg. H : Spermatheca.

Head with vertex shiny, with shallow reticulate punctures, forehead opaque, coriarious, with small punctures at periphery and impunctate in the middle, median fovea vestigial or at most with an indistinct short sulcus. Rostrum as long as pronotum, constricted at the base, tricarinate on basal half, median carina dilated apically and weakened before the basal two-thirds, with two rows of punctures and coriarious between carinae, shiny and with fine punctures on apical half. Antennae inserted a little before the middle of rostrum, funicle pubescent, first segment as long as second, robust, the remaining segments equal in length and successively broadened, club 2.3 times as long as broad, about as long as three basal segments of funicle combined, first segment as long as second, with slightly sinuate apical margin.

Pronotum slightly broader than long, broadest before the middle, straightly narrowed to the base or slightly constricted just before the hind angles, roundly narrowed to shallow subapical constriction, dorsum longitudinally convex basally and depressed in front, reticulately punctate, each puncture with a small scale and filled with earthy clothing, interstices coriarious, median shiny carina abbreviated on basal third. Scutellum subpentagonal, with a few punctures and minute setae.

Elytra 1.45-1.55 times as long as broad, slightly dilated posteriorly in a weak arc and broadest in or a little before the middle, subapical calli indistinct, striae with quadrate close punctures that diminish suddenly at apical third, intervals without a 
row of erect scales, a little narrower than punctures in the striae and much wider than their septa, flat on basal half, much wider than striae and weakly convex on apical third, third interval more or less incurved by subapical callus, conjointed area of third, seventh and ninth intervals behind subapical callus often convex.

Legs dull black, unci and tarsi dark reddish brown, with scattered dirty yellowish grey scales, without scaly rings, femora slightly clavate, with obtuse small teeth; tibiae very weakly bisinuate.

Underside coriarious, metasternum and first ventrite with clear-cut punctures, their interstices about half as broad as their diameters, median sulcus interrupted at basal third for a short distance ; second ventrite as closely punctate as on first but a little smaller, third and fourth ventrites each with a row of scaled punctures in the middle.

Aedeagus with penis broadest before the base and weakly narrowing apically, broadly rounded at apex, ventral wall broadly unsclerotized, with a median sclerotized round sensillum near apex, internal sac with a long flagellum, which is sclerotized at base and reaching to ostium in repose.

Female. Rostrum with median carina distinct on basal third, lateral carinae reaching the middle but weakend apically; antennae inserted in the middle of rostrum ; metasternum with a complete median sulcus ; first venter not depressed in the middle.

Length : 4.0-6.6 mm.

Holotype male (Type No. 2596, Kyushu Univ.), Mt. Aoidake, Miyazaki Pref., 6. viii. 1976, K. Morimoto leg.

Paratypes : Yunomata, Ohata-machi, Shimokita, Aomori Pref., $4 \varsigma^{73} 3$ 우, $11 \& 20$. vii. 1956, K. Morimoto leg. Kurokawa, Niigata Pref., $7 \sigma^{\nearrow}$, 4. vi. 1961, K. Baba leg. Mt. Fuji (Fuji-rindo), Yamanashi Pref., 2우, 26. vi. 1977, T. Ogasawara leg. Masutomi, Yamanashi Pref., 1ð, 24. vii. 1956, H. Kamiya leg. Mt. Ontake, Nagano Pref., 1 ð, 20. vii. 1952, S. Ueno leg. Misakubo, Shizuoka Pref., 1 우, 12. vii. 1954, K. Kojima leg. ;2 우, 24. viii. 1955, K. Kojima leg. Mt. Iwawaki, Osaka Pref., 1 구 1 우, 2 \& 9. vi. 1957, K. Ueda leg. Oomi-one, Kyoto Pref., $2 \sigma^{\top 2} 2$ ㅇ, 3. vii. 1979, Y. Sawada leg. Akazai, Shiso-gun, Hyogo Pref., $3 \sigma^{\top} 1$ 우, 23. vi. 1979, T. Takahashi leg. ;2 $\sigma^{\top}, 23$. vi, 1984, Y. Sawada leg. Arima, Kobe City, 16, 13. ix. 1979, D. Okamoto leg. Mt. Gomadan, Wakayama Pref., 1 우, 14. vii. 1973, I. Matoba leg. Mt. Daisen, Tottori Pref., 1우, 10. vii. 1951, S. Shibanai leg. Mt. Tebako, Kochi Pref., $1 \sigma^{7}, 8$. viii. 1962, K. Ueda leg. Mt. Hikosan, Fukuoka

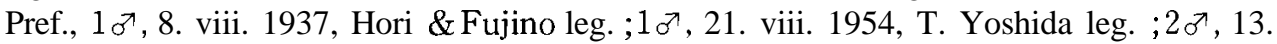
vi. 1957, K. Morimoto leg. ;2ð , 4. vi. 1958, K. Morimoto leg. ;2 Morimoto leg. Mt. Kumado, Hoshinomura, Fukuoka Pref., $1 \sigma^{7} 1$ 우, 1. viii. 1957, Y. Miyake leg. ; 2 우, 7. viii. 1958, Y. Miyake leg. ;1 $\Im^{7}, 29$. iv. 1959, Y. Miyake leg. ; 361 우, 3-21. viii. 1959, Y. Miyake leg. Mt. Kurodake, Kuju, Oita Pref., 2 우, 20. ix. 1985, S. Ogata leg. Mt. Sobo, Oita Pref., $1^{\top} 2$ 우, 24. vii. 1939, H. Tagawa leg. ;1 $\sigma^{\top}, 28$. vii. 1948, H. Doira leg. ;1우, 27. viii. 1952, Y. Miyake leg. Naidaijin, Kumamoto Pref., 1우, 29. vii. 1952, Takeya \& Hirashima leg. Same data as holotype, $6 \sigma^{7} 2$ 우. Cape Sata, Kagoshima Pref., $1 \sigma^{7} 1$ 우. 2-5. v. 1958, K. Morimoto leg. Kosugidani, Yaku I., $1 \sigma^{7} 1$ 우, 21. vii. 1950,

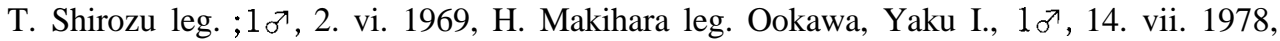
T. Takahashi leg. Ishizuka, Yaku I., 1 $\sigma^{7}$, 28. vi. 1965, S. Oga leg. Mt. Miyanouradake (1500 m), Yaku I., 1 우, 21. vii. 1974, T. Mikage leg. Miyanoura, Yaku I., 2 우, 28. vii. 1974, 
T. Mikage leg. Unsuikyo, Yaku I., $5 \diamond^{\prime} 1$ 우, 13-15. v. 1983, Y. Sawada leg.

Distribution : Japan (Honshu, Shikoku, Kyushu, Yakushima I.).

Specimens from Yakushima I., differ in general from those of the main land by the following points : the third interval of the elytron is distinctly sinuate by the subapical callus and more convex at the conjointed area behind the subapical callus.

This new species is close to R. maebarai, especially of the specimens covered with dirty clothing, but the elytra are broadest near the middle and the punctures are larger on the basal half. The male aedeagus is unique in this genus in having a long flagellum in the internal sac.

\section{Rhadinomerus ishigakianus sp. nov.}

(Figs, 4C ;7A)

Male. Derm dull black, pronotum without scaly patch, with greyish scales at apical margin ; elytra with three kinds of sparse scales, slender suberect scales arranged in a row on each interval, but often worn out on the back, oval scales forming. scattered indefinite small greyish patches, which are usually distinct on the base of third interval and on humeri, and often forming a variable transverse band on apical third, minute prostrate scales sparse on intervals.

Head with vertex bare, shiny, reticulately with shallow punctures, forehead weakly coriarious, punctate at sides, rugulose in the middle, with a deep median fovea, each side of the fovea raised and impunctate. Rostrum as long as pronotum, constricted at the base, sharply tricarinate on basal half, with a row of punctures between median and lateral carinae, with two rows of punctures between lateral carina and dorsal margin of scrobe, each puncture with a narrow scale, sparlingly puncticulate on apical half. Antennae inserted in the middle of rostrum, funicle thinly pubescent on apical three segments, first segment about 1.5 times as long as second, robust, third to seventh segments equal in length, sixth and seventh a little broader than the precedings, club as long as three basal segments of funicle combined, 2.2 times as long as broad, first segment oblique at apical margin, a little longer than second.

Pronotum slightly broader than long, broadest just before the middle, straightly and weakly narrowing posteriad, roundly narrowing anteriorly to the weak subapical constriction, dorsum longitudinally convex basally and weakly depressed in front, reticulate punctate, interstices coriarious, each puncture with a small brownish scale, a trace of median carina present before the middle. Scutellum convex, shiny, partly coriarious.

Elytra 1.63-1.67 times as long as broad, parallel-sided from humeri to the middle, subapical calli weak, striae with subquadrate punctures, their septa almost as broad as and on the same plane with intervals, the punctures diminished behind the middle, intervals convex on declivity.

Legs evenly and moderately covered with dirty greyish to reddish grey scales, basal area of femora not naked in ventral aspect, tibiae straight externally, fore tibiae scarcely bisunuate internally.

Underside opaque, metasternum punctate, their interstices as broad as the diameters, median shallow sulcus interrupted at the basal third for a short distance ; 

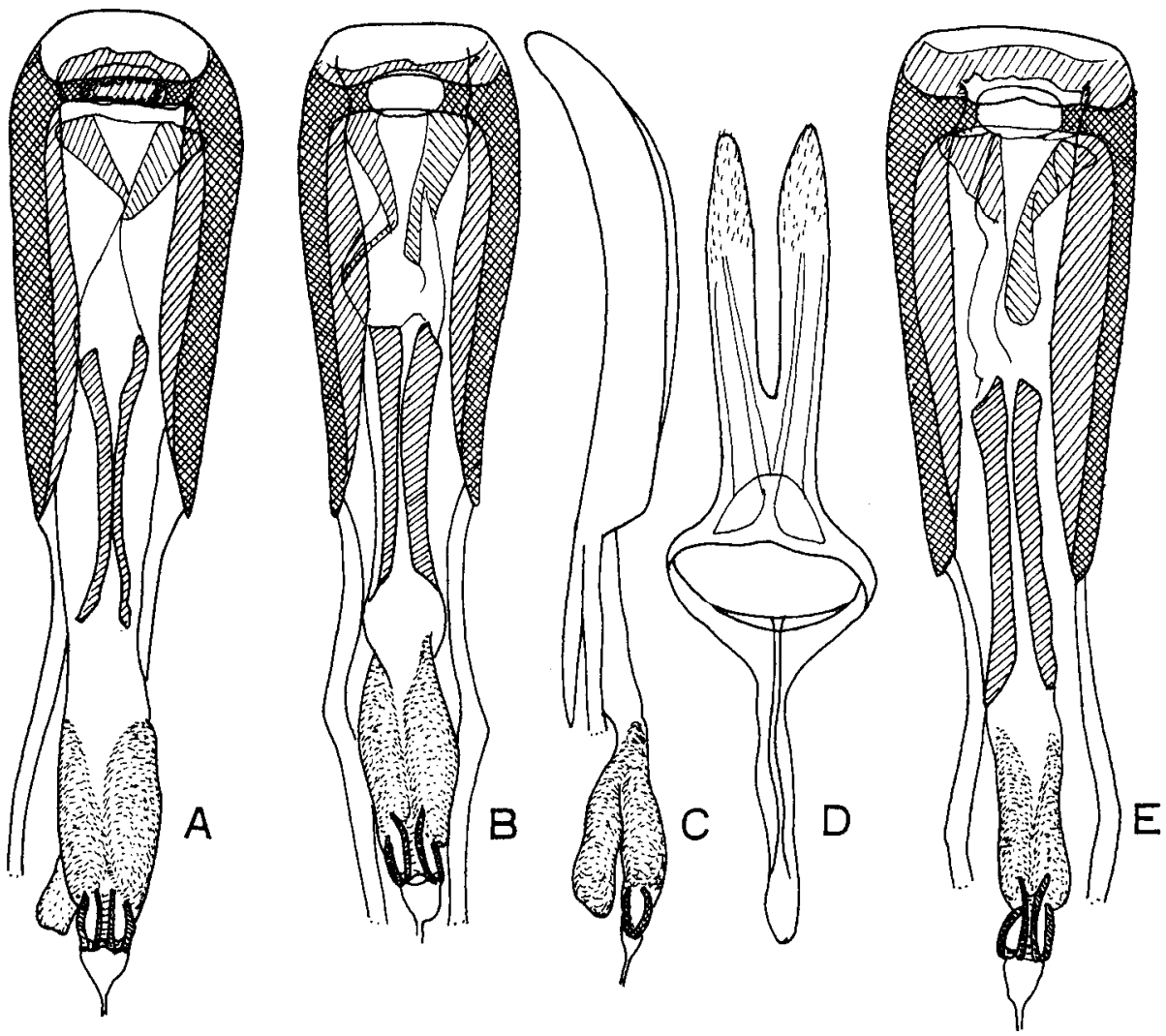

Fig. 7. Male genitalia of: A: Rhadinomerusishigakianus sp. nov., penis, dorsal. B-E: Rhadinomerus maebarai Chûjô et Voss. B: Penis, dorsal. C: Ditto, lateral. D : Tegmen and paramers. E : Penis, dorsal. (B-D : Mt. Tebko, Kochi; E : Ysku I.).

first ventrite with punctures sparser and smaller than those on metasternum, their interstices much broader than their diameters, second ventrite with scattered fine punctures, third and fourth ventrites each with a row of scales, puncutres indistinct.

Aedeagus with penis weakly dilated apically and broadly rounded at apex, apical orifice about half the width of penis, without median sensillum, gonopore with two short juxtaposed hairpin-shaped sclerites.

Female. Antennae inserted just behind the middle of rostrum; rostrum with median carina sharp from the base to basal fourth, then dilated apically and obliterated behind the antennal insertions, lateral carinae reaching the antennal insertions; metasternum similar to that of male, first ventrite not flattened in the middle.

Length : 4.1-7.3 mm.

Holotype male (Type No. 2597, Kyushu Univ.), Mt. Omotodake, Ishigaki I., 9. iv. 1974, 0. Yamaji leg.

Paratypes : Same locality as holotype, 1ㅇ, 17. xi. 1963, T. Yamasaki leg. ;1우, 9. vi.1974, O. Yamaji leg. ;1 의3우, 11. vi. 1974, T. Mikage leg. ;1워 1 우, 8-21. vi. 1975, H. 
Irie leg. Mt. Banna, Ishigaki I., $1 \sigma^{\top 2} 2$ 우, 7-9. ix. 1969, H. Makihara leg. Shirahama, Iriomote I., 1우. 31. viii. 1969, H. Makihara leg.

Distribution : Japan (Ryukyus : Ishigaki and Iriomote Isls.).

This is also close to R. maebarai, but the punctures on the second ventrite are very sparse and fine, and the elytra are clothed with three kinds of scales.

\section{R hadinomerus maebarai Chûjô et Voss}

(Figs. 7B-E; 8A)

Rhadinomenus maebarai Chûjô et Voss, 1960, Mem. Fac. Liberal Arts \&Educ., Kagawa Univ., Part II, No. 94 :6 (Berg Takachiho-holotype ; Berg Seppiko, Hyogo ; Hirayu, Gifu). -Morimoto, 1962,

Sci. Bull. Fac. Agr., Kyushu Univ., 19:352 (Honshu, Shikoku, Kyushu). - Nakanae, 1963, Icon. Ins. Jap. col. nat. ed., II : 379, pl. 185, fig. 16. -Morimoto. 1984, Coleopt. Jap. in col., IV :332, pl. 65, fig. 24. (Honshu, Shikoku, Kyushu).

Male. Derm dull black, septa of elytral striae often shiny and bare, pronotum with three indefinite stripes formed of scattered dirty grey scales ; elytra variegated with greyish and brownish scaly small indefinite patches, each interval with a row of scattered suberect scales on apical third.

Head with vertex bare, shiny and reticulately with shallow punctures, forehead coriarious, rugulose, scaled, deep median sulcus bordered laterally by narrow smooth areas. Rostrum as long as pronotum, constricted at the base, tricarinate on basal half, with two rows of scaled punctures between carinae, scales denser at the base, with sparse small punctures on apical half. Antennae inserted in the middle of rostrum, funicle sparsely pubescent on first and apical three segments, first segment robust, $9 / 7$ times as long as second, third segment a little longer than fourth, remaining segments equal in length and successively broadened, sixth segment as long as broad, club 2.4 times as long as broad, as long as three basal segments of funicle combined, first segment as long as broad, oblique or weakly sinuate at apex, a little longer than second.

Pronotum as long as broad, broadest in the middle, straightly narrowed posteriorly or very slightly constricted before the base, roundly narrowed anteriorly to the weak subapical constriction, dorsum longitudinally convex basally, median area more or less flattened and depressed in front, reticulately punctate, coriarious, with a short median carina before the middle. Scutellum bare, shiny, at most with a few minute punctures.

Elytra 1.6 times as long as broad, parallel-sided from humeri to the middle, subapical calli weak, striae with subquadrate punctures that diminished behind the middle, their septa as long as the width of punctures and much narrower than intervals on basal half, intervals almost as broad as striae on basal half, each interval with a row of scattered suberect scales at least on declivity.

Legs without scaly rings, femora scarcely clavate, not naked in ventral aspect ; tibiae straight.

Underside coriarious, metasternum with dense punctures, their interstices much narrower than the diameters, median sulcus deeper anteriorly, often interrupted near the base ; first ventrite punctate as on metasternum, second ventrite as densely punctate as on first, but they are much smaller and their interstices are broader than their diameters, third and fourth ventrites each with a row of scales, punctures 
indistinct in the middle.

Aedeagus with penis weakly dilated apically and broadly truncate at apex with round corners, without median sensillum, internal sac with two short juxtaposed hairpin-shaped sclerites.

Female. Antennae inserted just behind the middle of rostrum ; rostrum with weak three carinae at basal fourth and scaled at the base; metasternum with a shallow median sulcus often interrupted at basal third ; first ventrite not flattened in the middle.

Length : 3.3-6.8 mm.

Specimens examined: 198 specimens from Hokkaido (Ashoro), Aomori (Ohatamachi, Kodomari-son), Gunma (Mt. Shirane, Nikkosawa), Yamanashi (Masutomi), Nagano (Karuizawa, Mt. Asama, Tobiratoge, Mt. Kiso-Koma), Tokyo (Mt. Takao, Mikura I.), Chiba (Mt. Kiyosumi), Shizuoka (Misakubo, Kikengoya, Joto, Izu), Kyoto (Mt. Daihi), Mie (Misugi-son), Nara (Mt. Kohjin, Yoshino), Wakayama (Arida), Hyogo (Ashio), Tokushima (Jinryo-son), Kochi (Jinzenji, Erimon, Mt. Tebako, Makiyama, Monobe-son, Mt. Sasa in Hata), Fukuoka (Mt. Hikosan, Mt. Wakasugi, Mt. Fukuchi), Oita (Mt. Katamuki, Mt. Sobo), Kagoshima (Mt. Kirishima), Tsushima, and Yaku I.

Distribution : Japan (Hokkaido, Honshu, Mikura I., Shikoku, Kyushu, Tsushima, Yakushima I.).

Many specimens were captured on the bait logs of Pinus spp. set for the study of the pine boring beetles.

Specimens from Yakushima I. are usually slightly different from the main land ones by the following points : the elytra are more widely covered with blackish scales and visibly darker, the punctures in the striae are a little larger and as broad as the intervals.

\section{Parendymia Kirsch}

Parendymia Kirsch, 1877, Mitt. zool. Mus. Dresden, II : 154 (type-species : Parendymiu pilipes Kirsch, by monotypy). -Faust, 1893, Stett. ent. Zeit., LIV : 148 (comp.w. Mechistocerus and Rhadinomer. us). -Heller, 1937, Arb. morph. tex. Ent. Berlin-Dahlem, 4 : 270. -Morimoto, 1978, Esakia, (11) : 126.

Derm with oval or circular fluted scales and with narrow short suberect hairy scales.

Rostrum evenly curved, constricted laterally at the base. Antennae inserted in the apical third ( $\left.\sigma^{7}\right)$ or in the middle () of rostrum, funicle seven-segmented, second segment longer than the first, each segment longer than broad $\left(\sigma^{7}\right)$ or sixth and seventh as long as broad (ㅇ), club with first segment rectangular to the axis at apex, as long as second.

Pronotum transverse, subapical constriction obliterated indefinite, basal margin bisinuate. Scutellum with dense scales.

Elytra parallel-sided on basal half, subapical calli very weak or obsolete, tenth punctured stria diminished behind hind coxa.

Legs evenly scaled in ventral aspect ; femora cylindrical, not clavate, each with a small sharp tooth, hind femora reaching the apex of elytra (5) or middle of fifth 


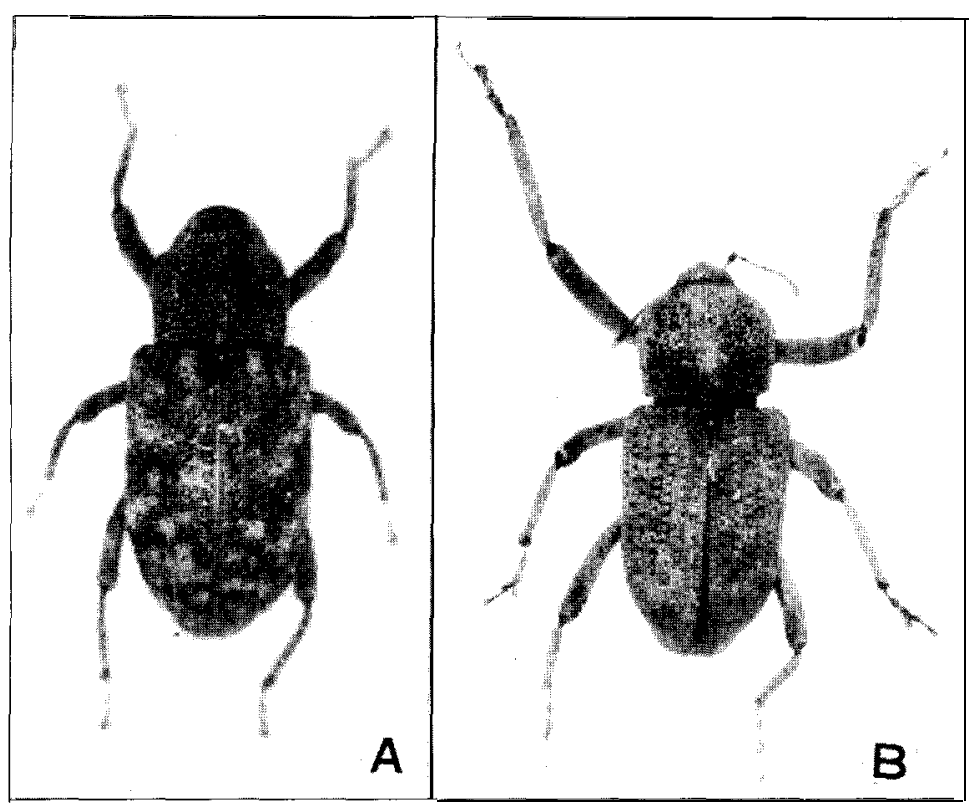

Fig. 8. A :Rhadinomerus maebarai Chûjô et Voss. B : Parendymia pilipes Kirsch, ơ (Iriomote I.).

ventrite(우); tibiae straight, fore tibiae fringed internally with long setae in male, tarsal grooves not ascended but obliquely truncate in fore and middle legs, outer setose fringe rectangularly bent in hind legs ; tarsi with second segment longer than broad, first and second segments with long setae externally and internally in male.

Pectoral canal reaching a little beyond the middle of hind coxae; metasternum transversely depressed behind receptacle, median sulcus definite on basal half; metepisternum with two rows of punctures at least on basal half ; first ventrite behind coxa shorter than second, the latter as long as third and fouth combined.

This genus contains three species at present, crinipes (Marshall, 1933), from the Andamans, kirschi Faust, 1898, from Key I., and pilipes Kirsch, 1877, and the latter is newly recorded from Japan in this paper. They are characteristic in the tribe Mechistocerini in having the visibly smooth derm, the fringed fore tibiae in the male, and the subcylindrical femora.

\section{Parendymia pilipes Kirsch}

(Figs. 8B ; 9)

Parendymia pilipes Kirsch, 1877, Mitt. zool. Mus. Dresden, II : 154 (Jobi). -Günther, 1937, Mitt. deut. ent. Ges., $8: 41$ (= atomosparsus Fairmaire; Solomon:Vella lavella, Aru, Japen, New Guinea, Vanikoro). -Morimoto, 1978, Esakia, (11) : 136, fig. 7.

Cyamobolus atomosparsus Fairmaire, 1878, Pet. Nouv, Ent.,: 282 (Viti). -Fairmaire, 1881, Ann. Soc. ent. Fr., (6) I : 308. 

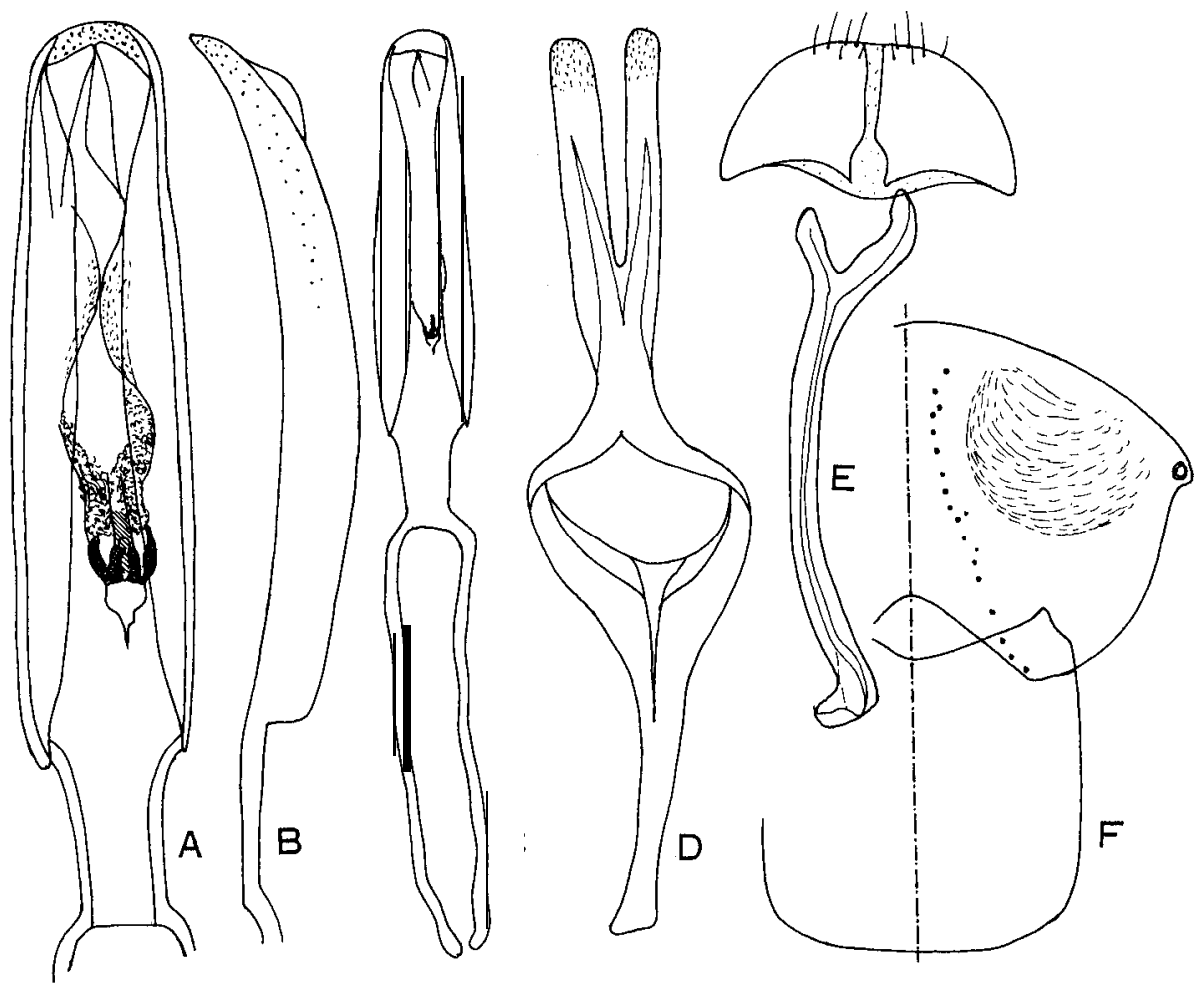

Fig. 9. Parendymia pilipes Kirsch, б. A : Penis, dorsal. B : Ditto, lateral. C : Whole penis. D : Tegmen and parameres. E : Genital segment. F : Pygidium and propygidium, showing arrangement of scrapers.

Mechistocerus atomosparsus: Hustache, 1936, Col. Cat., 151, Cryptorrhynchinae : 79 (=languidus Lea). Mecistocerus languidus Lea, 1907, Proc. Linn. Soc. N. S. Wales, XXXII : 413 (N. S. Wales). -Lea, 1913,

Trans. r. Soc. S. Austr., XXXVII : 322. -Lea, 1931, Rec. S. Austr. Mus., IV (3) : 406.

Male. Derm dull black, fairly densely clothed with ash-grey oval or circular scales, but most of the septa in the punctured striae on elytra bare and admedian areas on pronotum sparser, and sparsely clothed with small hair-like suberect scales.

Head with vertex densely punctate, forehead with dense overlapping scales and entirely conceal the sculpture, median fovea narrow ovate. Rostrum rugosely punctate and finely tricarinate in the basal two-thirds, the carinae converging basally to the median fovea, with irregular two rows of punctures between median and lateral carinae, and a row of punctures between lateral carina and scrobe, with dense scales at the basal portion, the apical part sparsely punctate. Antennae inserted at two-thirds from the base, scape clavate at apex, funicle with first and second segments sparsely and the remaining segments moderately pubescent, first segment $7 / 8$ times as long as second, 2.5 times as long as broad, second segment slender, 1.5 times as long as third, fourth to seventh segment equal in length, each much longer than broad, club three 
times as long as broad, first segment as long as second, as long as broad.

Pronotum 1.15 times as broad as long, broadest at apical two-fifths, straightly narrowed posteriorly, rather abruptly narrowed in an arc in front ; disk with small distant punctures and mostly concealed by large round or broadly ovate scales, the exposed punctures on each side of the middle bearing a suberect or recumbent hair-like scales, evenly convex longitudinally, exposed derm smooth, finely coriarious. Scutellum longer than broad, with dense greyish small scales.

Elytra 1.6 times as long as broad, parallel-sided from rectangular humeri to beyond the middle, suture fringed with small greyish scales in entire length, striae with oval punctures, each puncture on the basal half covered by a large scale, which is as large as those on pronotum and much larger than those on intervals, which diminish posteriorly and narrower than those on intervals on declivity, intervals with overlapped scales and a row of scattered recumbent hairlike short scales.

Legs with dense overlapped scales except for narrow bare spaces above the base of femora and scattered recumbent small scales.

Metasternum with sparse punctures, which concealed by broad scales at sides and mostly in the middle, some in the middle with narrow scales ; basal two ventrites similarly scaled as on metasternum, but a little smaller on second ventrite, third and fourth ventrites each with a row of scales in the middle.

Aedeagus with penis slender, broadly rounded at apex, ventral wall uniformly sclerotized, not extending basally between struts, internal sac short, not exposed, with an anchor-shaped sclerite at gonopore.

Female. Rostrum finely tricarinate at basal fourth, then with scattered small punctures to apex. Antennae inserted in the middle of rostrum, sixth and seventh segments of funicle each as long as broad. Fore tibiae and tarsi not adorned with long setae.

Length : $5.0-8.5 \mathrm{~mm}$.

Secimens examined : Ohara, Iriomote I., $10^{\rtimes}$, 31. viii. 1962, M. Chujo leg. 1 과 2 우, 5. vii. 1973, bred from a mangrove log imported from the Philippines to Japan.

Distribution : Fiji, Vanikolo, Solomons, Australia (N. S. Wales), New Guinea, Aru, Japen, Philippines (new record), Japan (new record).

Japanese material was compared with that from the Solomons identified by Marshall in the British Museum (Natural History).

\section{REFERENCES}

Chao. Y. and Y. Q. Chen 1980 Economic entomology in China, 20. Curculionidae (1). Science Publ. Co., Peking. (in Chinese)

Chûjô, M. and E. Voss 1960 Neue Curculioniden-Subfamilie, -Gattungen und-Arten von Japan. Mem. Fac. Liberal Art \& Educ., Kagawa Univ., II (94): 1-17

Fairmaire, L. M. H. 1878 Diagnoses de Colêoptères des îles Viti, Samoa, etc. Petites Nouv. Ent. 1 (10) : 282

Fairmaire, L. M. H. 1881 Essai sur les Coléoptères des ̂̂les Viti (Fidgi). Ann. Soc. ent. France, (6) 1: $243-318,461-492$

Faust, J. 1892 Notizen über Rüsselkäfer. Stett. ent. Zeit., LIII: 44-52

Faust, J. 1892 Curculioniden aus dem Malayischen Archipel. Stett. ent. Zeit., LIII : 184-228

Faust, J. 1894 Viaggio de Leonardo Fea in Birmania e regioni vicine. LX. Curculionidae. Ann. Mus.Civ.Stor. Nat. Genova, (2) XIV (XXXIV): 153-370 
Faust, J. 1898 Curculioniden aus dem Malayischen und Polynesischen Inselgebiet. II. Stett. ent. Zeit., LIX : 140-213

Günther, K. 1937 Über einige Curculioniden von den Salomon-Inseln. Mitt. deut. ent. Ges., 8 : $37-$ 43

Heller, K. M. 1904 Beitrage zur Kenntnis der Insektenfauna von Kamerun. No. 27. Rtisselkafer aus Kamerun gesammelt von Prof. Dr. Yngve Sjostedt. Ent. Tidskr., $25: 161-201$

Heller, K. M. 1921 New Philippine Coleoptera. Philipp.J.Sci., 19: 523-625, 3 pls

Heller, K. M. 1922 Curculioniden aus Franzosisch-Indochina. Deut. ent. Zeit., 1922 :1-25

Heller, K. M. 1931 H. Sauter's Formosa-Ausbeute, Wien. ent. Ztg., 48: 96-112

Heller, K. M. 1937 Neue Papuanische Rtisselkafer. Arb. morph. tax. Ent. Berlin-Dahlem, 4 :257$282,1 \mathrm{pl}$.

Heller, K. M. 1940 Indomalayische Rüsselkäfer II. Arb. morph. tax. Ent. Berlin-Dahlem, 7: 92-113, pl. 2

Hustache, A. 1924 Synopsis des Curculionides de Madagascar. Bull. Acad.Malg., N. S., VII :1-582 Hustache, A. 1936 Coleopterorum Catalogus. 151. Cryptorrhynchinae. 317 pp. 's-Gravenhage

Kirsch, T. F. W. 1877 Beitrag zur Kenntniss der Coleopteren-Fauna von Neu Guinea. Mitt. zool. Mus. Dresden, II: 135-161

Kôno, H. 1932 Elf neue Curculioniden aus Japan und Formosa. Ins. mats., VI : 173-182, pl. vi

Kôo, H. 1950 Curculionidae. In "Iconographia Insectorum Japonicorum," ed. by T. Esaki et al., Hokuryukan, Tokyo. (in Japanese)

Lacordaire, T. 1866 Genera des Coléoptèrs. VII. 620 pp. Paris

Lea, A. M. 1907 Revision of the Australian Curculionidae belonging to the subfamily Cryptorhynchides. Part VIII. Proc.Linn.Soc. N.S. Wales, XXX11 (2) : 400-430

Lea, A.M. 1913 Descriptions of Australian Curculionidae, with notes on previously described species. Part II. Trans. r.Soc.S.Austr., 37: 301-445

Lea, A. M. 1928 Cryptorhynchides (Curculionidae) mostly from Australia. Rec. S.Austr. Mus., 4 : 49-90

Lea, A. 1931 Australasian Coleoptera. Rec. S. Austr. Mus., 4: 365-408, 1 pl.

Marshall, G. A. K. 1921 On new species of Curculionidae attacking forest trees in India. Bull. ent. Res., XII: 165-180

Marshall. G. A. K. 1931 New Indian Curculionidae. Indian For. Rec., XVI :263-278, pl. 1

Marshall, G. A. K. 1933 On new Indian Curculionidae. Ann. Mag. nat. Hist., (10) XII :565-583

Marshall, G. A. K. 1939 New tropical African Curculionidae. Ann. Mag. nat. Hist., (11) 3 : 561-583

Marshall, G. A. K. 1948 Entomological results from the Swedish expedition 1934 to Burma and British India - Coleoptera : Curculionidae. Novit. Zool., 42 : 397-473

Marshall, G. A. K. 1957 A synopsis of the South African Rhadinomerus. Ann. Mag. nat. Hist., (12) $X: 846$

Marshall, G. A. K. 1958 New Cryptorhynchinae from the Belgian Congo. Rev. Zool. Bot. afr., LVIII : 249-262

Morimoto, K. 1962 Key to families, subfamilies, tribes and genera of the superfamily Curculionoidea of Japan excluding Scolytidae, Platypodidae and Cossoninae. J.Fac. Agr., Kyushu Univ., 12 : 21-66

Morimoto, K. 1978 On the genera of oriental Cryptorhynchinae. Esakia, (11) :121-143, 62 figs.

Morimoto, K. 1984 The Coleoptera of Japan in Color, IV. Hoikusha, Osaka (in Japanese)

Morimoto, K. and S. Miyakawa 1985 Weevil fauna of the Izu Islands, Japan. Mushi, 50: 19-85

Nakane, T. 1963 New or little-known Coleoptera from Japan and its adjacent regions. XX. Fragm. Coleopt., pars 8-10:31-40

Nakane, T. 1963 Iconographia Insectorum Japonicorum colorenaturali edita, II. Hokuryukan, Tokyo (in Japanese)

Voss, E. 1958 Ein Beitrag zur Kenntnis der Curculioniden im Grenzgebiet der Orientalischen zur Palaarktischen Region. Decheniana, Beihefte 5 : 1-139 